\title{
POLITICAL KNOWLEDGE: THEORETICAL FORMULATIONS AND PRACTICAL IMPLEMENTATION
}

\author{
D. Pastarmadzhieva* \\ Department of Political Science, Faculty of International Economics and Politics, University of \\ National and World Economy, Sofia, Bulgaria
}

\begin{abstract}
Political knowledge is a key concept in the theory of political culture. Political culture reflects the political values in the society, modifies the political system and is modified by the latter. This element of political culture which defines the civic values and behavior and is an object which can be defined is the political knowledge. The democracy needs competent citizens and requires a certain level of knowledge on political matters - theoretical knowledge and knowledge about current political leaders and events. The purpose of this paper is to systematize theoretical formulations concerning political knowledge and the approaches for its empirical study. In this sense the main questions of the current work are: $1 /$ why the political knowledge is significant?; 2 / what is the definition of "political knowledge"?; $3 /$ how the political knowledge is studied empirically?

The main tasks of the study are as follows: 1/ theoretical examination of sources on political knowledge; 2/ summary of suggested definitions; 3/ comparison of "political knowledge" with similar or related categories; 4/ examination of empirical studies on political knowledge. The main methods used are comparative approach and analysis of the content.
\end{abstract}

Key words: political knowledge, political culture, democracy

\section{INTRODUCTION}

A basic element of the democratic political culture is the participation of citizens in the political process. The factor that determines competent political participation is political knowledge (1). Political knowledge is directly related to citizen's participation as a key element of the democratic political culture. The congruence between political system and political culture leads to political stability and the latter contributes to economic growth.

The functioning of democracy in Bulgaria is still an object of many critics and dissatisfaction. In $201384 \%$ of all Bulgarians believe that it is important to live in democratically governed country but only $15 \%$ of them consider Bulgaria as a democratic one (Figure 1). There are many reasons for the dissatisfaction - some are subjective but others correspond to the actual weaknesses of political process. Reasonably, a lot of

\footnotetext{
*Correspondence to: Daniela Pastarmadzhieva, Bulgaria, 1606 Sofia, 29 Sv. Ivan Rilski str. Tel.: +359884 727096 e-mail:

daniela.pastarmadjieva@gmail.com
}

Bulgarians ask why twenty five years after the beginning of democratic transition their social and financial status is still far from the European average. Bulgaria has the institutions that are relevant to a democratic government and a functioning market economy (2) but these are not enough. The formal establishment of democracy doesn't automatically lead to a functioning democratic society. The stability of the latter can be achieved only if there is a corresponding political culture among the society and political elites $(3,4)$.

In this study the category "political knowledge" is analyzed on five different criteria: $1 /$ the role and functions of political knowledge in democratic societies; 2/ definition of "political knowledge"; 3/ content and formation of political knowledge; 4/ related categories; 5/ empirical measurement of political knowledge. The results of the current research are based on review of over fifty sources, some of which dealt with "political knowledge" as a theoretical category, while others are specific empirical analyzes. 


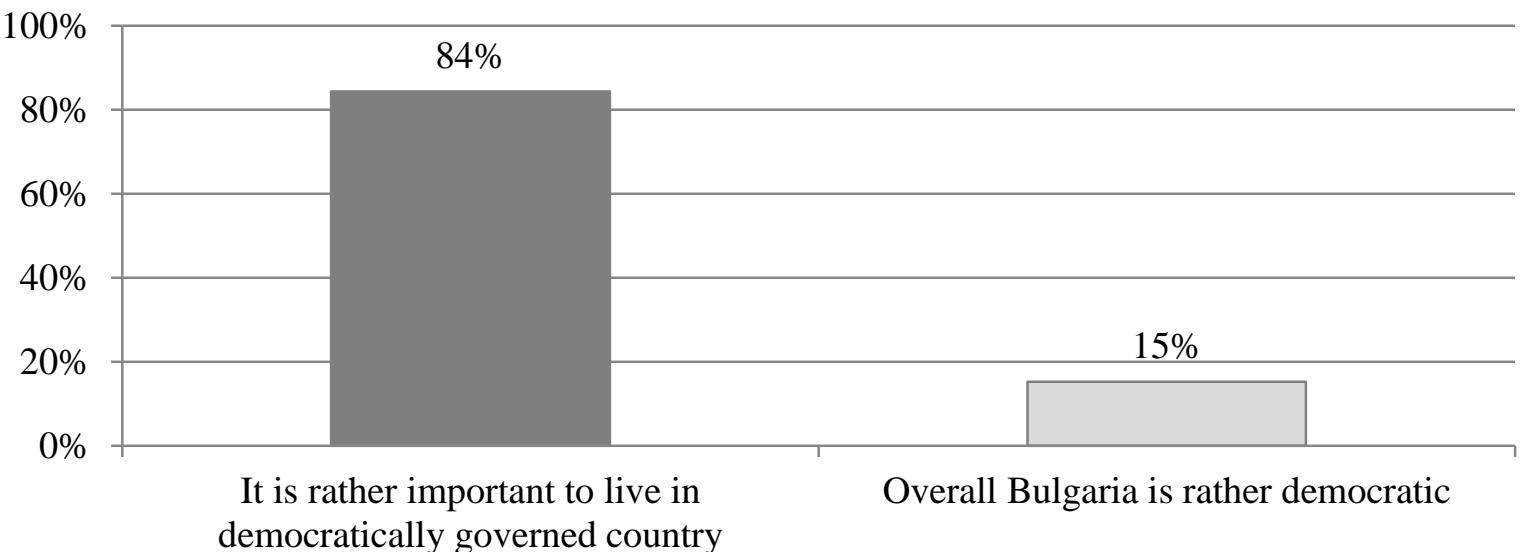

Figure1. Opinion on democracy in general and in Bulgaria, 2013 Source of data: European Social Survey, 2013

\section{ROLE AND FUNCTIONS}

The examination of a scientific category requires arguments for its significance. This is why the current study suggests several reasons for the importance of political knowledge. But first of all an answer to the following question should be provided - for whom (or what) the political knowledge is important? In general, knowledge and education play a significant role for individual and public progress. The same is valid for political knowledge but its role refers to the civic participation which is part of development and stability of democracy. In non-democratic countries the attempts of the society to participate in political life are often regarded as a deviant behavior. In this sense it can be concluded that the political knowledge is important only for societies with democratic political system. But why is it important for democratic societies? Can't they function with no or limited political knowledge? Does the lack of political knowledge among society and political elite compromises democracy?

The democracy requires political knowledge both among the politicians ${ }^{1}$ and the members of society. It can't function properly and successfully with no or limited political knowledge and the lack of such knowledge do

\footnotetext{
${ }^{1}$ When measuring the knowledge of political elites it should be noted that it may depend on their way of recruitment. The latter is related to the traditions in every single state- whether the elites generally come from higher social strata or from the masses. Some may expect that representatives of higher social strata have more political knowledge but it is an assumption which should be examined for every studied national context.
}

compromises the democracy. The reasons for its significance contain in the role and functions of political knowledge in democratic societies.

First, in democratically governed countries political elite is supposed to have a certain level of political knowledge. The determination of this level is not subject to this investigation but it is necessary for politicians to possess cognition of the basic democratic principles, knowledge about the role of government and politics, political institutions and processes, political players, etc. In order to perform their duties properly politicians should be aware of what they are expected to do and not to do in accordance to democratic principles; how they are supposed to act in a democratic environment; how they should treat society and its attempts to participate in political life; how are they expected to communicate with their political opponents. These are just a small part of all the important issues for which politicians in democratic countries should have political knowledge. In summary, the level of political knowledge among the elites affects the overall functioning of the government and democracy in a country. Second, democracy requires active citizens and political knowledge affects this activity in several ways. Democracy doesn't require just any kind of social activity - it requires a competent participation. Political knowledge is an essential ingredient of democratic civic competence. In fact the latter requires acquisition of knowledge about politics. Without an education which leads to knowledge of politics, citizens' attempts to participate can't be defined as competent. 
Furthermore, some citizens refuse to participate in politics because they don't understand it. Due to political knowledge citizens can understand the content of the public debate and perform an informed political participation. (5)

Almost every citizen has expectation toward life, society and politicians. Nevertheless, very often individuals don't find connection between their personal expectations and politics. Through political knowledge, citizens can rationalize and understand their own interests. It affects the content of beliefs, opinions, preferences and attitudes and in this sense impacts the political and electoral preferences. (5)

When political values of the citizens are rationalized it is a prerequisite which can increase the stability of political attitudes and ideological consistency. Latter leads to stability in the political behavior and particularly in voting. (5)

\section{DEFINITION}

Once the significance of political knowledge in the democratic societies has been cleared, it is important to understand what the concept "political knowledge" means according to the scientists. Each theoretical analysis or empirical study of political knowledge suggests a definition for the category. Some authors offer their own definition but most of the researchers refer to some of the most authoritative studies. Among the latter is the work of Delli Carpini and Keeter "What Americans know about politics and why it matters". Many authors refer to their understanding of political knowledge, which is "the range of factual information about politics that is stored in long-term memory". The authors explain the meaning of every single word in their definition and how it helps in understanding of the concept. The notion of "range" is chosen to demonstrate the broadness of the idea and the relation with its components. It gives possibility to set different levels of knowledge by using additional qualifiers. According to Delli Carpini and Keeter "factual" means that "political knowledge" differs from incorrect cognitions or ones that can't be tested for correctness; and "information" distinguishes political knowledge from attitudes, values, beliefs, and opinions. As regards "stored in long-term memory" it means that political knowledge doesn't apply to "information that is never cognized or that is used in short-term memory but then discarded". (6)
Another popular interpretation on political knowledge is offered in Cambridge Handbook of Experimental Political Science. Boudreau and Lupia defined political knowledge as "a measure of citizen's ability to provide correct answers to a specific set of fact-based questions" (7). As in Delli Carpini and Keeter' definition it again comes to "facts". Nevertheless, such definition connects the political knowledge with its empirical measurements and the knowledge is limited to the questions asked. In this case there is no allpurpose content of knowledge but is determined for every single research.

In his study "Contextual Dynamics and Political Knowledge: The Role of Institutional Quality in an Informed Citizenry" Nick Clark offers a definition which sounds like an improved version of Delli Carpini and Keeter's suggestion. According to him political knowledge refers to "facts about a political system that an individual can recall from their memory to interpret and understand happenings and developments within that system". (8) This definition is broader because besides the static knowledge of the individual, it emphasize on the practical implementation of this knowledge. The author of this study believes that this definition most comprehensively describes the concept of political knowledge.

\section{CONTENT AND FORMATION}

As all the cited definitions reveal political knowledge incorporates knowledge about specific facts. But what are these facts and do all the studies deal with the same facts? First of all, the range of the facts which form the content of political knowledge may vary depending on the purpose of the study. Nevertheless, there are some general facts that are object of almost every empirical study but there aren't any all-purpose facts. These general facts can be grouped into two main categories (8):

1/ General knowledge, which is a theoretical knowledge about the political system and the political process, including knowledge concerning the structures, institutions and actors in the political system. It includes knowledge about basic theoretical categories such as state, power, politics, democracy, political parties, elections, parliament, government, etc.

2/ Specific knowledge. It incorporates knowledge about current political process, as well as specific policies and issues, parties, political leaders, representatives of the political elite and others. 
Where the knowledge of the first category is advanced enough, the second type of knowledge can be competently and authentically analyzed and interpreted.

In the English-language scientific literature on political knowledge, the latter is often replaced with "democratic knowledge" (9) and "civic knowledge" (1). At first glance, political knowledge might seem like a broad concept encompassing an expert knowledge about the politics in a general sense. Studies of political knowledge, however, focus on the analysis of knowledge among the general public and therefore the notions mentioned above are used interchangeably. The latter is related to the affiliation of "political knowledge" to the theory of democracy. It is an object of examination in national contexts where citizens' participation is perceived by the politicians as a normal and expected behavior, not an anti-social activity.

Acquisition of political knowledge is performed in the process of political socialization. The factors of socialization that form the political knowledge may differ. Nevertheless, most people are exposed to the same influences, or agents of political socialization, especially in childhood until adolescence. These influences include family, school, community, peers and media (10). The best instrument for formation of a broader political knowledge is the civic education taught in schools.

\section{RELATED CATEGORIES}

On the basis of the studies reviewed several broad categories related to political knowledge can be drawn, namely: political culture, political information, public education, public opinion, civil competence.

\section{Political knowledge and political culture}

The founders of the modern theory of political culture Gabriel Almond and Sidney Verba in their study "The Civic Culture: Political Attitudes and Democracy in Five Nations" compare political cultures of five nations (USA, United Kingdom, Mexico, Germany and Italy) to check to what degree each of them can support democratic political system. One of the indicators of comparison is the political knowledge. According to them the participatory type of political culture requires a clear view and awareness of the political system in both government and politics. (3)

In the contemporary political analysis, "political knowledge" is accepted as part of the structure of political culture along with political values, political norms and traditions, models of political behavior, political ideas and political ideals. (11)

\section{Political knowledge and political information}

In some of the analyzed sources "political knowledge" and "political information" are used as synonyms. Nevertheless, there are authors who examined the relationship between these categories and they derived a certain connection between them. The results of specific empirical analyze show that where political information is available, the level of political knowledge increases (12). As a result the accumulation of political knowledge contributes to the proper analysis of the political information.

Political information can be defined as the information received through the media about the current events in the political process and about the behavior of political actors. (13)

\section{Political knowledge and civic education}

An important factor that contributes to the formation of political knowledge is education. In particular, this applies to civic education. It has an impact on political knowledge, both directly and indirectly. Civic education affects it directly by leading to acquisition of specific political knowledge and indirectly - by creating interest in politics and a sense of civic duty, which contributes to the absorption of political knowledge long after individuals leave the classroom. (14)

\section{Political knowledge and public opinion}

Some authors put political knowledge at the core of the study of public opinion and political behavior. (12) Public opinion on political matters is an active expression of political culture. It covers subjective attitudes towards political objects. (13) Those attitudes, in turn, are formed under the influence and represent a reflection of political knowledge possessed by the society.

\section{Political knowledge and civic competence}

In the theory of political culture, political competence is an element of the orientations toward own political activity (13). Two main components are mentioned in the structure of political competence - active and cognitive. Active components refer to how often and in what ways individuals participate in political life and cognitive refer to knowledge about: political and legal system, democracy, role of media, functioning of voluntary associations, history, culture and current events (15). That largely coincides with the content of political knowledge. 
MEASUREMENT OF POLITICAL KNOWLEDGE

The current work doesn't intend to describe the statistical procedures in the measurement of political knowledge but to set the frame of its empirical study. The measurement of political knowledge is rather complex and depends on its content. Object of such studies is not "THE political knowledge" but "A political knowledge". That's why every researcher should define the "facts" that form the content of political knowledge in order to operationalize the concept.

This need is determined by three main conditions: 1/ lack of definition that describes the entire content of political knowledge which should be tested; 2/ every empirical study of political knowledge have its specific purpose. Furthermore, the authors of political knowledge analysis very often use an empirical data already collected and therefore they tie down their analysis to the 3/ available information.

But what are the approaches used for measuring the political knowledge? In the broadest sense, political knowledge is measured by $1 /$ asking respondents questions concerning the political system and the political process and 2/ the correct answers indicate a level of existence of political knowledge and the wrong - lack of such (16). A more thorough analysis of political knowledge take into account 3/ additional factors influencing it as gender, age, education, access to information and others. (12)

\section{CONCLUSION}

Political knowledge is a concept related to the theory of democracy. The notion is used in the behavioral approach in the political science. It affects the civic competence and the behavior both of the elites and societies. The most important instrument for its formation is the civic education taught in schools. Political knowledge can be broadly defined as the knowledge of individuals about stable and dynamic elements of political sphere of social life. The content of political knowledge is determined for every single research. Usually, political knowledge of a given society or social group is measured by quantitative methods of empirical study (surveys) or by usage of already collected date from such surveys.

The author of this work believes that the study of political knowledge is of particular importance in Bulgaria for two reasons:

1/ For the identification of levels of political knowledge among different social groups in Bulgarian society. This process requires theoretical expertise on the concept and the preparation of relevant questionnaire for the empirical measurement.

2/ For the elaboration of strategy for the improvement of political knowledge where its levels are problematic. The implementation of such strategy may lead to increase in competent civic participation, democracy support and rationalized political demands.

Political knowledge is not offered as a universal solution for the problems of democracy but it can contribute for better performance. A lot of factors may lead for better democratic environment in Bulgaria and political knowledge is one of them.

\section{REFERENCES}

1. Galston, W., Political knowledge, political engagement and civic education", Annual Review of Political Science, 4 (1): pp. 217234, 2001

2. Regular report on Bulgaria's progress towards accession, Commission of the European communities, Brussels, 9.10.2002

3. Almond, G., Verba, S., The Civic Culture: Political Attitudes and Democracy in Five Nations. SAGE, 1989

4. Dahrendorf, R., Reflections on the Revolution in Europe. Transaction Publishers, 1990

5. Oost, M., Knowledge about the European Union and its predictors in twenty-five European Countries. Leiden University, 2012

6. Delli Carpini, M. X., \& Keeter, S., What Americans know about politics and why it matters. New Haven, CT: Yale University Press, 1996

7. Boudreau, C., Lupia, A., Political knowledge, In: Druckman, J., Green, D., Kuklinski, J., Lupia, A., Cambridge Handbook of Experimental Political Science, Cambridge University Press, pp 171-186, 2011

8. Clark, N., Contextual Dynamics and Political Knowledge: The Role of Institutional Quality in an Informed Citizenry, Susquehanna University, 2013

9. Norris, P., Democratic Deficit: Critical Citizens Revisited, Cambridge University Press, 2011

10.Janda, K., Berry, J., Goldman, J., Schildkraut, D., Hula, K,. The Challenge of Democracy: American Government in Global Politics, 13 ed., Wadsworth Publishing, 2015

11.Blagoeva, B1. Political culture and political socialization, In: Todorov, A. et al., Fundamentals of political sociology, KIA Plovdiv, pp. 130-157, 2014 
12.Barabas, J., Jerit, J., Pollock, W., Rainey, C., The Question(s) of Political Knowledge, American Political Science Review, 108 (4): pp. 1-16, 2014

13.Tanev, T., The political culture. UI „Sv.Kliment Ohridski”, 2012

14. Owen, D., Chalif, R. and Soule, S., Civic Education and Knowledge of Government and Politics, APSA Annual Meeting Paper, 2011, http://ssrn.com/abstract=1903270
15.Hoskins, Br., Barber, C., Nijlen, D., Villabla, E. Comparing Civic Competence among European Youth: Composite and Domain-Specific Indicators Using IEA Civic Education Study Data, Comparative Education Review, 55 (1): pp. 82-110, 2011

16.Mondak, J., Reconsidering the Measurement of Political Knowledge, Political Analysis, 8 (1): pp. 57-82, 1999 